\title{
Rearing of the Nile tilapia (Oreochromis niloticus) on diets containing cotton seed meal enriched with vitamin $\mathrm{E}$
}

\author{
Magdy A. Soltan ${ }^{1}$, Abdel-Nasser M. Saudy ${ }^{2}$ and Ahmed F. Fath El-Bab ${ }^{3}$ \\ 1. Faculty of Agriculture, Moshtohor, Banha University, Egypt. \\ 2. National Organization for Drug Control and Research, Egypt. \\ 3. Central Laboratory for Aquaculture Research - Abbassa, Sharkyia governorate
}

\begin{abstract}
$\mathrm{T}$ he present experiment was conducted to evaluate the effect of $\alpha$-tocopherol as an antioxidant for avoiding the side effects of incorporation of cottonseed meal (CSM) in the diet of the Nile tilapia as a replacer of fish meal (FM). Two diets were prepared; the first one contained fish meal and was considered as a control, in the second diet, FM was completely replaced by CSM. The second diet was divided into ten parts, the first one is a control and the other 9 diets were enriched with increased levels of vitamin $\mathrm{E}(1,5,10,15,20,25,30,35$ and 40 times of gossypol in CSM). Each diet was offered in three aquaria (3 replicates for each diet) and each aquarium was stocked with 25 fish (2.0-2.1g). Results are summarized in the following:

- The highest average body weight $(9.91 \mathrm{~g})$ was recorded for the control group fed on the basal diet (contained FM) and the lowest BW (5.66 g) was obtained for fish fed the diet D2 in which FM was completely replaced by CSM without vitamin E. Incorporation of vitamin $\mathrm{E}$ in the experimental diet significantly improved the BW. Similar trend was observed for the other growth performance parameters body length (BL), weight gain (WG) and specific growth rate (SGR).

- The best feed conversion ratio (FCR) was recorded for fish group fed on the diets D1 and D3 which significantly differed from values recorded for the other treatments. The worst FCR was recorded in fish group fed on the diet D2 in which FM was completely replaced by CSM without addition of vitamin E. Incorporation of vitamin E in the experimental diets improved FCR specially fish group fed on the diet D3.

- Protein content of the whole fish body ranged between 41.33 to $50.97 \%$ and the differences were significant. Fat content of fish fed the diet D2 significantly higher than those obtained for fish fed the other groups. Compared to the two control diets D1 and D2 all vitamin levels in the experimental diets increased ash content of the fish whole body and the graded levels of vitamin $\mathrm{E}$ in the diets significantly altered the ash content of tilapia fish.

- The highest values for hematocrite $(\mathrm{Ht})$ and haemoglobin $(\mathrm{Hb})$ were obtained for fish fed on the control diet (D1). Incorporation of vitamin E in the experimental diets at increasing levels significantly affected $\mathrm{Hb}$ and $\mathrm{Ht}$. Compared to the control group (Diet1) aspartate transaminase (AST) and alanine transaminase (ALT) levels significantly increased fish groups fed on the other experimental diets.
\end{abstract}

Keywords: Nile tilapia, diet, cotton seed, vitamin E, growth rate 


\section{INTRODUCTION}

The high cost of fish meal in tilapia diets warrants the potential use of cottonseed meal (CCM) as an alternative source of high quality protein. Cottonseed, Gossypium hirsute Linnaeus, is the third leading legume seed by weight (after soybean and rapeseed) used worldwide. Owing to its high protein value for animals (Alford et al., 1996) as well as low market price in comparison with other legumes and fish meal, cottonseed meal (CSM) consequently has an immense potential for incorporation in high-protein aquafeeds. Lee et al. (2006) summarized a series of studies in rainbow trout where CSM replaced fish meal entirely over the 3-year period without significantly impacting growth rate of female and male rainbow trout. In the study of Robinson and $\mathrm{Li}$ (1994), channel catfish, Ictalurus punctatus, were fed to satiation a diet containing 51\% CSM with supplemented lysine $(0.65 \%)$. Results indicated that growth rate, dressing percentage and chemical composition of the fillets did not differ significantly from fish fed diets containing SBM (42\%).

Cottonseed meal typically contains about $400-800 \mathrm{mg}$ of free gossypol $\mathrm{kg}^{-}{ }^{1}$, a compound recognized for its toxicity to animals, especially in regard to reproduction. Gossypol accumulated in the liver when trout were fed $1000 \mathrm{mg}$ of gossypol acetate $\mathrm{kg}^{-}{ }^{1}$ diet for several months. In tilapia Oreochromis sp. detoxification of gossypol from CSM prevent inhibition of pepsin and trypsin, as well as accelerating removal of gossypol via bile and post-absorptive transport. Impaired absorption of gossypol may allow complete utilization of CSM protein, and realization of growth-promoting effects, for instance, via flavonoid contributions (antioxidant action) or steroidogenesis, as stimulation of testosterone concentrations have been observed in rainbow trout (Dabrowski et al., 2000) and tilapia (Rinchard et al., 2002).

Free gossypol, when present in large quantity in the diet, has been shown to be toxic to monogastric animals including fish. Growth depression occurred in channel catfish fed diets containing more than $900 \mathrm{mg}$ free gossypol $/ \mathrm{kg}$ diet (Dorsa et al., 1982), whereas a diet containing as low as $290 \mathrm{mg}$ free gossypol/kg diet reduced the growth of rainbow trout (Herman, 1970). Iron as ferrous sulfate, has been successfully used to counteract the toxicity of free gossypol in diets of monogastric, terrestrial animals. High level of supplemental iron used to counteract the toxicity of gossypol may be harmful to fish because it has been suggested that a delicate balance exists between the need of iron for host defense mechanisms and the need of iron to sustain microbial growth.

Free gossypol is known to bind lysine rendering it less bioavailable (Wilson et al., 1981). Gossypol or other compounds present in CSM may have a beneficial effect by improving the immune response and the resistance of juvenile channel catfish against E. ictaluri infection as evidence by increased macrophage chemotaxis, improved survival and continued consumption of diets containing CSM. 
Garcia-Abiado, et al. (2004) reported that, fish fed 25-50\% CSM protein replacement showed similar body weight and total lengths as the controls at the completion of the 16-week trial. Fish fed 75 and $100 \%$ CSM protein replacement showed a significant decline in body weight and total length. Fish fed $25-100 \%$ CSM protein replacement had significantly lower haematocrit and haemoglobin compared with levels in controls. The same authors reported that, pathological effects of gossypol in tilapia (low haemoglobin and haematocrit levels, abundance of immature red blood cells or polychromatocytes, abnormal spleen morphology) were similar to the effects of vitamin $\mathrm{E}$ and/or vitamin $\mathrm{C}$ deficiencies in other studies.

Therefore, The present experiment was conducted to evaluate the effect of $\alpha$ tocopherol as an antioxidant for avoiding the side effects of incorporation of cottonseed meal (CSM) in the diet of the Nile tilapia as a replacer of fish meal (FM).

\section{MATERIALS AND METHODS}

Nile tilapia fingerlings were obtained from The World Fish Center at Abbassa, Sharkiya Governorate, Egypt and acclimated to laboratory conditions in 1700-L fibreglass tanks. The feeding trial was performed at the Fish Nutrition Lab (Fac. Agric., Benha University, Egypt).

\section{Experimental design:}

The present experiment aimed to evaluate the effect of $\alpha$-tocopherol dietary incorporation as an antioxidant for avoiding the side effects of replacing of CSM in the diets of Nile tilapia instead of FM. Two diets were prepared; the first one contained fish meal and considered a control, in the second diet fish meal was completely replaced by CSM. The second diet was divided into ten parts, the first one is a control and the other 9 diets were enriched by increased levels of vitamin $\mathrm{E}(1,5,10,15,20,25,30,35$ and 40 times of gossypol content of cotton seed). Each diet examined was offered in three aquaria (3 replicates for each diet). Therefore 33 rectangular aquaria $100 \times 40 \times 50 \mathrm{~cm}(180$ liter for each) were used for the experiment and each aquarium was stocked with 25 fish.

The practical work of the present study started at $9^{\text {th }}$ of December 2006 and lased at the $9^{\text {th }}$ March 2007. The fish were grouped into eleven groups and each group was arranged in three aquaria and fed on the experimental diets.

\section{Diets preparation and feeding practices:}

The different diets of the present experiment were formulated as described in Table (1). Diets of the experiment were prepared by thoroughly mixing the ingredients which composed of fish meal, soybean meal, cotton seed meal, yellow corn, vegetable oil and wheat bran. In preparing the diets, dry ingredients were first ground to a small particle size. Ingredients were mixed and then water was added to obtain a $30 \%$ moisture level. Diets were passed through a mincer machine with diameter of $2 \mathrm{~mm}$ and were sun-dried for 3 days. All diets were formulated to be 
isonitrogenous (30\% protein) and isocaloric [2700 kcal metabolizable energy $(\mathrm{ME}) / \mathrm{kg}$ diet].

Tilapia fry were fed on the pelleted diets ( $2 \mathrm{~mm}$ in diameter) at a daily rate of $10 \%$ (during the $1^{\text {st }}$ month), then gradually decreased to $7 \%\left(2^{\text {nd }}\right.$ month) and $4 \%\left(3^{\text {rd }}\right.$ month $)$ of total biomass. Nile tilapia fed on the experimental diets 6 day/week (twice daily at 9.00 am and $3.00 \mathrm{pm}$ ) and the amount of feed was biweekly readjusted according to the changes in body weight throughout the experimental period (90 days). About $25 \%$ of water volume in each aquarium was daily replaced by aerated fresh water after cleaning and removing the accumulated excreta. Water temperature, $\mathrm{pH}$ and dissolved oxygen were measured daily at $2.00 \mathrm{pm}$, while total ammonia was weekly measured. Water quality parameters were found to be within the acceptable limits for fish growth and health (Boyd, 1979).

Table 1: Composition and proximate analysis of the experimental diets

\begin{tabular}{|c|c|c|c|c|c|c|c|c|c|c|c|}
\hline \multirow{2}{*}{$\begin{array}{l}\text { Ingredients } \\
\text { Ingredients }\end{array}$} & \multicolumn{11}{|c|}{ Diets } \\
\hline & D1 & D2 & D3 & D4 & D5 & D6 & D7 & D8 & D9 & D10 & D11 \\
\hline Fish meal & 200 & 0 & 0 & 0 & 0 & 0 & 0 & 0 & 0 & 0 & 0 \\
\hline Soy bean meal & 300 & 300 & 300 & 300 & 300 & 300 & 300 & 300 & 300 & 300 & 300 \\
\hline Yellow corn & 350 & 350 & 350 & 350 & 350 & 350 & 350 & 350 & 350 & 350 & 350 \\
\hline Cottonseed & 0 & 260 & 260 & 260 & 260 & 260 & 260 & 260 & 260 & 260 & 260 \\
\hline Corn oil & 20 & 20 & 20 & 20 & 20 & 20 & 20 & 20 & 20 & 20 & 20 \\
\hline Wheat bran & 100 & 40 & 40 & 40 & 40 & 40 & 40 & 40 & 40 & 40 & 40 \\
\hline Min\&vit.* & 30 & 30 & 30 & 30 & 30 & 30 & 30 & 30 & 30 & 30 & 30 \\
\hline Vitamin E (IU) $\mathrm{kg}^{-1}$ & - & - & 36.4 & 182 & 364 & 546 & 728 & 910 & 1092 & 1274 & 1456 \\
\hline Total & 100 & 100 & 100 & 100 & 100 & 100 & 100 & 100 & 100 & 100 & 100 \\
\hline \multicolumn{12}{|l|}{ Dry matter (DM) } \\
\hline Crude protein $(\mathrm{CP})$ & 30.36 & 29.88 & 29.88 & 29.88 & 29.88 & 29.88 & 29.88 & 29.88 & 29.88 & 29.88 & 29.88 \\
\hline Ether extract (EE) & 4.44 & 5.00 & 5.00 & 5.00 & 5.00 & 5.00 & 5.00 & 5.00 & 5.00 & 5.00 & 5.00 \\
\hline Ash & 8.32 & 9.12 & 9.12 & 9.12 & 9.12 & 9.12 & 9.12 & 9.12 & 9.12 & 9.12 & 9.12 \\
\hline Crude fiber & 5.35 & 6.22 & 6.22 & 6.22 & 6.22 & 6.22 & 6.22 & 6.22 & 6.22 & 6.22 & 6.22 \\
\hline $\mathrm{NFE}^{2}$ & 51.53 & 49.78 & 49.78 & 49.78 & 49.78 & 49.78 & 49.78 & 49.78 & 49.78 & 49.78 & 49.78 \\
\hline ME (Kcal/kg diet $)^{3}$ & 2748 & 2692 & 2692 & 2692 & 2692 & 2692 & 2692 & 2692 & 2692 & 2692 & 2692 \\
\hline $\mathrm{P} /$ E ratio $^{4}$ & 110.48 & 111 & 111 & 111 & 111 & 111 & 111 & 111 & 111 & 111 & 111 \\
\hline
\end{tabular}

${ }^{*}$ Vitamin \& mineral mixture/kg premix: Vitamin $\mathrm{D}_{3}, 0.8$ million IU; A, 4.8 million IU; E, 4 g; K, 0.8 g; B1, 0.4 g; Riboflavin, 1.6 g; B6, 0.6 g, B12, 4 mg; Pantothenic acid, 4 g; Nicotinic acid, 8 g; Folic acid, 0.4 g Biotin, 20 mg, Mn, 22 g; Zn, 22 g; Fe, 12 g; Cu, 4 g; I, $0.4 \mathrm{~g}$, Selenium, $0.4 \mathrm{~g}$ and Co, $4.8 \mathrm{mg}$.

2 Nitrogen free extract $(\mathrm{NFE})=100-(\mathrm{CP}+\mathrm{EE}+\mathrm{CF}+\mathrm{Ash})$

3 Metabolizable energy was calculated from ingredients based on NRC (1993) values for tilapia.

4 Protein to energy ratio in $\mathrm{mg}$ protein/Kcal ME.

Growth and feed utilization parameters: Growth performance and feed utilization parameters were determined according to Cho and Kaushik (1985) as follows:

Specific growth rate $(\mathrm{SGR})=[(\mathrm{LnW} 2-\mathrm{LnW} 1) / \mathrm{t}] \times 100$ Where:- $\mathrm{Ln}=$ the natural $\log , \mathrm{W} 1=$ initial fish weight; $\mathrm{W} 2=$ the final fish weight in "grams" and $\mathrm{t}=$ period in days. 
Feed conversion ratio $(\mathrm{FCR})=$ feed intake $(\mathrm{g}) /$ wet weight gain $(\mathrm{g})$, Protein efficiency ratio $($ PER $)=$ weight gain $(\mathrm{g}) /$ protein intake $(\mathrm{g})$,

Blood samples and liver function: Blood samples were obtained from fish at the end of experimental period. Five fish per tank were randomly chosen and anaesthetized by ethylene glycol mono-phenol ether. Blood samples were collected from the caudal vein using heparinized 27-gauge needles and tuberculin syringes. Hematocrite $(\mathrm{Ht})$ was determined using the micro-Ht method described by Brown (1988). Hemoglobin ( $\mathrm{Hb}$ ) was determined using the total $\mathrm{Hb}$ kit (Sigma Diagnostics, Sigma, St Louis, MO. USA) which is standardized procedure using the cyanomethemoglobin method. Liver was removed, homogenized and assigned for determination of Aspartate transaminase (AST) and Alanine transaminase (ALT) according to (Reitman and Frankel, 1957).

\section{Determination of gossypol in CSM:}

Gossypol content of CSM was determined by HPLC as described by Yang and Xiang (1995).

Chemical analysis: At termination of the experiment, three fish were randomly sampled from each tank and subjected to the chemical analysis of the whole fish body. Chemical analysis of fish, diets and feces were determined according to the methods of AOAC (1990).

Statistical analysis: The statistical analysis of data was carried out by applying the computer program, SAS (1996) by adopting the model: $Y i j=\mu+\alpha i+$ eij Where, Yij $=$ the observation on the $\mathrm{j}^{\text {th }}$ fish eaten the $\mathrm{i}^{\text {th }}$ diet; $\mu=$ overall mean, $\alpha_{\mathrm{i}}=$ the effect of $i^{\text {th }}$ diet and $e_{i j}=$ random error.

\section{Growth performance}

\section{RESULTS AND DISCUSSION}

The initial body weight (BW) of the Nile tilapia $O$. niloticus ranged from 2.0 to $2.1 \mathrm{~g}$ and the differences among these means were insignificant (Table 2). At the experiment termination (after 90 days) the average BW ranged between 5.66 to $9.91 \mathrm{~g}$ and the difference in BW among the different treatments were significant $(\mathrm{P}<0.001)$ and the same trend was observed for the other growth performance parameters (BL, WG and SGR).

The highest average BW (9.91 g) was recorded for the control group fed on the basal diet (contained fish meal) and the lowest BW (5.66 g) was obtained for fish fed the diet D2 in which fish meal was completely replaced by CSM without vitamin E. Results of the same table indicated that, incorporation of vitamin $\mathrm{E}$ in the experimental diet significantly improved the final BW (compared to fish group fed the diet D2) because the anti-oxidant effect of vitamin E in the other experimental diets and the best ratio between gossypol and vitamin $\mathrm{E}$ was found to be 1:1 (D3). Anderson and Sunderland (2002) reported that, $\alpha$-tocopheryl acetate, is the form of vitamin E commonly added to fish feed, becomes active 
as antioxidant only after the hydrolysis of the acetate group in the fish body, and can not be sacrificed in the feed as an antioxidant.

As described in Table (2) the initial condition factor for fish received the experimental diets ranged between 2.87 and 4.50 with significant differences in $\mathrm{K}$ values. At the experimental termination (after 90 days for the experimental start) the highest average condition factor (2.71) was recorded for fish group fed the diet $\mathrm{D} 2$ and the differences in $\mathrm{K}$ values of Nile tilapia significantly $(\mathrm{P}<0.05)$ affected by the different experimental treatments.

Table 2: Least square means and standard error for the effect of replacing fish meal by cotton seed meal and different levels of V.E in Nile tilapia diets on body weight, body length and condition factor.

\begin{tabular}{|l|c|c|c|c|c|c|c|}
\hline \multirow{2}{*}{ Diets } & & \multicolumn{2}{|c|}{ Body weight (BW)/gm } & \multicolumn{2}{c|}{ Body length (Bl)/cm } & \multicolumn{2}{c|}{ Condition factor $(\mathrm{K})$} \\
\cline { 2 - 8 } & No. & Initial & Final & Initial & Final & Initial & Final \\
\hline Diet 1 (Control) & 50 & 2.04 & $9.91 \mathrm{a}$ & 4.10 & $7.59 \mathrm{a}$ & $2.87 \mathrm{c}$ & $2.18 \mathrm{e}$ \\
\hline Diet 2 (CSM) & 50 & 2.00 & $5.66 \mathrm{~d}$ & 4.00 & $5.55 \mathrm{~d}$ & $3.18 \mathrm{c}$ & $2.71 \mathrm{a}$ \\
\hline Diet 3(G:V. E 1:1) & 50 & 2.00 & $8.21 \mathrm{~b}$ & 4.01 & $7.11 \mathrm{~b}$ & $2.92 \mathrm{c}$ & $2.41 \mathrm{c}$ \\
\hline Diet 4 (G:V. E 1:5) & 50 & 2.00 & $7.78 \mathrm{~b}$ & 4.10 & $7.03 \mathrm{~b}$ & $3.00 \mathrm{c}$ & $2.23 \mathrm{~d}$ \\
\hline Diet 5 (G:V.E1:10) & 50 & 2.03 & $7.12 \mathrm{cb}$ & 4.10 & $7.11 \mathrm{~b}$ & $3.04 \mathrm{c}$ & $2.31 \mathrm{~d}$ \\
\hline Diet 6 (G:V.E 1:15) & 50 & 2.00 & $7.00 \mathrm{cb}$ & 4.00 & $6.68 \mathrm{cb}$ & $2.96 \mathrm{c}$ & $2.43 \mathrm{c}$ \\
\hline Diet 7 (G:V.E 1:20) & 50 & 2.10 & $7.67 \mathrm{~b}$ & 4.04 & $7.11 \mathrm{~b}$ & $4.50 \mathrm{a}$ & $1.97 \mathrm{f}$ \\
\hline Diet 8 (G:V.E 1:25) & 50 & 2.00 & $6.22 \mathrm{~cd}$ & 4.00 & $6.61 \mathrm{cb}$ & $3.30 \mathrm{c}$ & $2.15 \mathrm{e}$ \\
\hline Diet 9 (G:V.E 1:30) & 50 & 2.00 & $6.96 \mathrm{cb}$ & 4.00 & $6.61 \mathrm{cb}$ & $4.16 \mathrm{ab}$ & $2.40 \mathrm{c}$ \\
\hline Diet 10 (G:V.E 1:35) & 50 & 2.02 & $7.11 \mathrm{cb}$ & 4.11 & $6.53 \mathrm{cb}$ & $2.98 \mathrm{c}$ & $2.59 \mathrm{~b}$ \\
\hline Diet 11(G:V.E 1:40) & 50 & 2.00 & $7.21 \mathrm{cb}$ & $3 . .88$ & $6.65 \mathrm{cb}$ & $3.20 \mathrm{c}$ & $2.53 \mathrm{~b}$ \\
\hline Standard error & & \pm 0.12 & \pm 0.41 & \pm 0.11 & \pm 0.17 & \pm 0.30 & \pm 0.11 \\
\hline
\end{tabular}

Averages followed by different letters in each column are significantly different $(\mathrm{P}<0.05)$

Iron as ferrous sulphate has been successfully used to counteract the toxicity of free gossypol in diets of monogastric terrestrial animals (Jones, 1987 and Martin, 1990). High levels of supplemental iron used to counteract the toxicity of gossypol may be harmful to fish because it has been suggested that a delicate balance exists between the need of iron for host defiance mechanisms and the need of iron to sustain microbial growth. Sealey et al. (1997) reported that high levels of dietary iron may lead to increased susceptibility of channel catfish to Edwardsiella ictaluri infection. In the study of Barros et al. (2002) three basal diets containing $0,27.5$ or $55.0 \%$ solvent-extracted cottonseed meal as replacements of 0,50 or $100 \%$ of solvent-extracted soybean meal with three levels of iron $\left(40,336,671 \mathrm{mg} \mathrm{k}^{-1}\right)$ in $3 \times 3$ factorial experiment and fed to juvenile channel catfish for 10 weeks. The authors found that, the average weight gain pooled by dietary CSM levels showed that fish fed the $55.0 \%$ CSM diets had significantly $(\mathrm{P}<0.05)$ lower weight gain $(\mathrm{WG})$ than the groups fed diets without or with $27.5 \% \mathrm{CSM}$. The dietary levels of iron had no significant effect on WG but the interaction between CSM and iron was significant. In the same study, the authors indicated that, at the higher level of dietary iron (671 
$\mathrm{mg} \mathrm{k}^{-1}$ ), there was a linear decrease in WG with increasing level of CSM and fish fed diets containing 0 and 55\% CSM had the highest and lowest WG, respectively.

Early studies have indicated that the amount of CSM in the Nile tilapia feed depends mainly on the level of free gossypol and available lysine content of the diet. Rosbinson et al. (1984) found that O. aureus fed CSM-based diets yield poor performance. The authors attributed the poor performance to the gossypol in CSM. On contrary rapressed solvent-extracted CSM was successfully used as a single dietary protein source for O. mossambicus (Jackson et al., 1982) and Nile tilapia (El-Sayed, 1990). El-Saidy and Gaber (2003) indicated that, regardless of supplemental levels of iron, fish fed diets that contained $67 \%$ CSM (972 mg free gossypol) supplemented with lysine to level equal to that of the fish meal (FM) diet and supplemented with $972 \mathrm{mg} \mathrm{Fe} / \mathrm{kg}$ diet exhibited better BW and SGR than those fed diet (67\% CSM without additional iron). This may be due to the fact that addition of iron sulphate at a weight ratio of 1:1 of iron to free gossypol was effective in reducing the toxicity of free gossypol and improving their performances.

\section{Feed utilization:}

The average feed intake (FI), feed conversion ratio (FCR) and protein efficiency ratio (PER) are outlined in Table (3). As described in this table, the highest feed intake values were recorded for the control diet (contained fish meal) which significantly different from those obtained in the other treatments. The high-crude fiber and poor platability of CSM may reduce FI.

The best FCR value was recorded in fish group fed the diets D1 and D3 which significantly different from FCR recorded in the other treatments. The worst FCR was recorded in fish group fed the diet D2 in which FM was completely replaced by CSM without addition of vitamin E. Incorporation of vitamin $\mathrm{E}$ in the experimental diets improved FCR specially fish group fed the diet D3.

In the study of Barros et al. (2002) three basal diets containing 0, 27.5 or $55.0 \%$ solvent-extracted cottonseed meal as replacements of 0,50 or $100 \%$ of solvent-extracted soybean meal with three levels of iron $\left(40,336,671 \mathrm{mg} \mathrm{k}^{-1}\right)$ in $3 \times 3$ factorial experiment and fed to juvenile channel catfish for 10 weeks. FI, FCR and PER was similar for diets containing 0 and $27.5 \%$ CSM but was significantly lower for diets containing 55.0\% CSM. Dietary levels of supplemental iron had no effect on FI, FCR and PER but the interaction between CSM and iron was significant. For diets without CSM, there was a linear increased in FI, FCR and PER with increasing dietary level of iron. For diets without CSM, there was a linear increased in FI with increasing dietary level of iron. For diets containing 55.5\%CSM, the effect of increasing dietary iron on FI, FCR and PER was quadratic with fish fed diet supplemented with $336 \mathrm{mg}$ iron/ $\mathrm{kg}$ having the lowest FI. At a dietary level of iron of $336 \mathrm{mg} / \mathrm{kg}$ diet, FI of the 0 and $27.5 \%$ CSM diets was similar but the value was significantly lower for 
the $55.0 \% \mathrm{CSM}$ diet. At $671 \mathrm{mg} / \mathrm{kg}$ of dietary iron, FI linearly decreased with increasing dietary level of CSM (Barros et al., 2002).

Table 3: Least square means and standard error for the effect of replacing fish meal by cottonseed meal and different levels of V.E in Nile tilapia diets on growth and feed utilization parameters (Feed intake Feed conversion ratio and Protein efficiency ratio)

\begin{tabular}{|l|c|c|c|c|c|c|}
\hline Diets & No.+ & $\begin{array}{c}\text { Weight } \\
\text { gain } \\
\text { (g/fish) }\end{array}$ & $\begin{array}{c}\text { Specific } \\
\text { growth } \\
\text { rate }\end{array}$ & $\begin{array}{c}\text { Feed } \\
\text { intake } \\
\text { (gm/fish }\end{array}$ & $\begin{array}{c}\text { Feed } \\
\text { conversion } \\
\text { ratio }\end{array}$ & $\begin{array}{c}\text { Protein } \\
\text { efficiency } \\
\text { ratio }\end{array}$ \\
\hline Diet 1 (Control) & 2 & $7.87 \mathrm{a}$ & $1.78 \mathrm{a}$ & $18.78 \mathrm{a}$ & $2.38 \mathrm{f}$ & $1.41 \mathrm{a}$ \\
\hline Diet 2 (CSM) & 2 & $3.64 \mathrm{e}$ & $1.18 \mathrm{~d}$ & $13.92 \mathrm{cb}$ & $3.82 \mathrm{a}$ & $0.87 \mathrm{~d}$ \\
\hline Diet 3(G:V. E) (1:1) & 2 & $6.40 \mathrm{ba}$ & $1.61 \mathrm{~b}$ & $15.14 \mathrm{~b}$ & $2.36 \mathrm{f}$ & $1.42 \mathrm{a}$ \\
\hline Diet 4 (G:V. E) (1:5) & 2 & $5.79 \mathrm{~b}$ & $1.52 \mathrm{bc}$ & $15.88 \mathrm{~b}$ & $2.74 \mathrm{~d}$ & $1.22 \mathrm{c}$ \\
\hline Diet 5 (G:V. E) (1:10) & 2 & $5.17 \mathrm{c}$ & $1.41 \mathrm{c}$ & $15.44 \mathrm{~b}$ & $2.98 \mathrm{c}$ & $1.12 \mathrm{c}$ \\
\hline Diet 6 (G:V. E) (1:15) & 2 & $5.37 \mathrm{c}$ & $1.51 \mathrm{c}$ & $13.77 \mathrm{cb}$ & $2.56 \mathrm{e}$ & $1.31 \mathrm{~b}$ \\
\hline Diet 7 (G:V. E) $(1: 20)$ & 2 & $4.99 \mathrm{c}$ & $1.21 \mathrm{c}$ & $15.49 \mathrm{~b}$ & $3.10 \mathrm{~b}$ & $1.10 \mathrm{c}$ \\
\hline Diet 8 (G:V.E) (1:25) & 2 & $4.21 \mathrm{~d}$ & $1.31 \mathrm{c}$ & $15.33 \mathrm{~b}$ & $3.64 \mathrm{a}$ & $0.92 \mathrm{~d}$ \\
\hline Diet 9 (G:V. E) (1:30) & 2 & $4.93 \mathrm{c}$ & $1.41 \mathrm{c}$ & $14.72 \mathrm{~b}$ & $2.88 \mathrm{c}$ & $1.16 \mathrm{c}$ \\
\hline Diet 10 (G:V.E 1:35) & 2 & $5.26 \mathrm{c}$ & $1.40 \mathrm{c}$ & $15.22 \mathrm{~b}$ & $2.89 \mathrm{c}$ & $1.15 \mathrm{c}$ \\
\hline Diet 11 (G:V. E 1:40) & 2 & $5.25 \mathrm{c}$ & $1.47 \mathrm{c}$ & $13.99 \mathrm{cb}$ & $2.66 \mathrm{~d}$ & $1.25 \mathrm{bc}$ \\
\hline Standard error & 2 & \pm 0.56 & \pm 0.07 & \pm 0.62 & \pm 0.09 & \pm 0.08 \\
\hline
\end{tabular}

Averages followed by different letters in each column are significantly different $(\mathrm{P}<0.05)$

In the same study, Barros et al. (2002) reported that channel catfish fed a diet containing $50 \% \mathrm{CSM}$ and supplemented with $671 \mathrm{mg} \mathrm{Fe} \mathrm{kg}$ diet had no improvement in growth of fish or the haematological values compared to treatments without dietary iron added. They attributed that to diets high in SBM may contain compounds or factors, which reduce iron absorption or availability. It is well known that the rate of digestion and nutrients assimilation in fish may be influenced by various physiological and a biotic factors, including fish, size, ration level and temperature (NRC 1993). EL Saidy and Gaber (2002) showed that total replacement of FM with CSM (0.145\% free gossypol)reduced the nutritional value of diets. For cottonseed meal containing diets, supplemented with iron, as ferrous sulphate at 1:1 ratio of iron to free gossypol had no effects on the nutritional value of the diets. In addition iron presents in practical diets at a level of $972 \mathrm{mg} \mathrm{Fe} / \mathrm{kg}$ diet appears to be sufficient to maintain normal function of growth performance, feed utilization and biological and haematological parameters of Nile tilapia.

\section{Blood parameters:}

The highest values for hematocrite $(\mathrm{Ht})$ and hemoglobin $(\mathrm{Hb})$ were obtained for fish fed the control diet (D1). Incorporation of vitamin E in the experimental diets at increasing levels significantly decreased each of hematocrite and haemoglobin values. El-Saidy and Gaber (2004) indicated that, the response of fish based on $\mathrm{Ht}$ and $\mathrm{Hb}$ to dietary CSM was influenced by supplemental levels of dietary iron. For diets containing no CSM (fish meal based diets), there was an 
increase in these parameters. When FM was completely replaced by CSM (67\%) supplemented with 972.1458 and $1944 \mathrm{mg} \mathrm{Fe} / \mathrm{kg}$ diet exhibited superior results of $\mathrm{Ht}, \mathrm{Hb}$ and $\mathrm{RBC}$ to fish meal diet. Barros et al. (2002) found that, $\mathrm{Ht}$ and $\mathrm{Hb}$ were not significantly affected by dietary level of CSM. $\mathrm{Ht}$ and $\mathrm{Hb}$, however, were not affected by dietary iron level. Interaction between dietary levels of CSM and iron were significant for $\mathrm{Hb}$ but had no effect on $\mathrm{Ht}$. And $\mathrm{Hb}$ values decreased linearly with increasing dietary level of iron. Another major finding of this study was the similarity in patholobical effects of gossypol in tilapia (low $\mathrm{Hb}$ and $\mathrm{Ht}$ levels) with the effects of vitamin $\mathrm{E}$ and/or vitamin $\mathrm{C}$ deficiency in juvenile rainbow trout (Moccia et al., 1984 \& Frischnecht et al., 1994). It is possible that gossypol also interferes with cell membrane integrity hence inducing erythrocyte fragility (Fu et al., 1988).

Middendorp and Huisman (1995) and Middendorp (1995 a, b) with Nile tilapia, Oreochromis spp. reared under semi-intensive and intensive culture reported that, a polyphenolic substance with known toxic effects on fish that include growth depression, reduced haematocrit and haemoglobin, as well as total plasma protein, and liver and kidney damage (Herman, 1970). Free gossypol is a membrane active agent with cytocidal properties and has the ability to inhibit membrane bound enzymes, causing hemolytic anemia at high concentrations in mammals. The cytotoxic effects of gossypol include increase in red blood cell fragility and accurrence of hypokalaemia in animal models (Colin-Negrete et al., 1996; Randel et al., 1996; Nikokyris, et al., 1999).

Rinchard et al. (2000) showed that haemoglobin and haematocrit decreased significantly when adult rainbow trout, Oncorbynchus mykiss, were fed a diet containing $100 \%$ CSM protein as fish meal protein replacement. This suggests that the properties of fish blood are sensitive to physiological and pathological changes (Hibiya 1982) that are associated with gossypol toxicity.

Garcia-Abiado, et al., (2004) showed that increasing concentration of total gossypol in the diets $(0.11-0.44 \%)$ resulted in a proportional increase of total gossypol in fish liver. The same authors provides supporting evidence on the deleterious effects of gossypol on $\mathrm{Ht}$ and $\mathrm{Hb}$ levels in tilapia blood, frequency of immature/abnormal erythrocytes, and accurrence of spleen abnormalities.

It has been shown that free gossypol traps iron causing anaemia and erythrocyte fragility (Nikokyris et al. 1999). In swine, gossypol feeding resulted in iron deficiency anemia, because of binding of iron by the gossypol, which resulted in low $\mathrm{Hb}$ and $\mathrm{Ht}$ and the high iron-binding capacity of blood serum (Nikokris et al., 1999). Erythrocyte fragility of Holstein dairy heifers fed diets containing 0 or $15 \%$ whole cottonseed were similar, bur lower than that for heifers fed the $30 \%$ whole cottonseed diets, suggesting that effects of gossypol are concentration dependent (Colin-Negrete et al.,1996).

\section{Liver functions:}

Changes in liver enzymes (AST and ALT) are outlined in Table ( 4 ) as described in this table, compared to control group (Diet1) AST and ALT levels 
significantly increased for fish groups fed the other experimental diets and the differences were significant.

Table 4: Least square means and standard error for the effect of replacing fish meal by cotton seed meal and different levels of V.E in Nile tilapia diets on blood parameters.

\begin{tabular}{|l|c|c|c|c|c|}
\hline Diets & No. & $\mathrm{Ht}$ & $\mathrm{Hb}$ & $\mathrm{AST}$ & ALT \\
\hline Diet 1 (Control) & 4 & $26.73 \mathrm{a}$ & $11.16 \mathrm{a}$ & $110.0 \mathrm{e}$ & $81.66 \mathrm{c}$ \\
\hline Diet 2 (CSM) & 4 & $17.30 \mathrm{e}$ & $4.96 \mathrm{~h}$ & $147.66 \mathrm{c}$ & $152.0 \mathrm{a}$ \\
\hline Diet 3(G:V. E 1:1) & 4 & $20.63 \mathrm{c}$ & $7.33 \mathrm{ed}$ & $155.0 \mathrm{abc}$ & $154.0 \mathrm{a}$ \\
\hline Diet 4 (G:V. E 1:5) & 4 & $14.22 \mathrm{f}$ & $5.00 \mathrm{~h}$ & $150.66 \mathrm{bc}$ & $155.6 \mathrm{a}$ \\
\hline Diet 5 (G:V.E1:10) & 4 & $20.65 \mathrm{c}$ & $5.15 \mathrm{~g}$ & $155.0 \mathrm{abc}$ & $155.3 \mathrm{a}$ \\
\hline Diet 6 (G:V.E 1:15) & 4 & $26.45 \mathrm{a}$ & $9.35 \mathrm{bc}$ & $150.16 \mathrm{abc}$ & $153.5 \mathrm{a}$ \\
\hline Diet 7 (G:V.E 1:20) & 4 & $19.40 \mathrm{~d}$ & $7.10 \mathrm{e}$ & $149.66 \mathrm{bc}$ & $146.5 \mathrm{a}$ \\
\hline Diet 8 (G:V.E 1:25) & 4 & $23.37 \mathrm{~b}$ & $9.03 \mathrm{c}$ & $158.0 \mathrm{ab}$ & $148.0 \mathrm{a}$ \\
\hline Diet 9 (G:V.E 1:30) & 4 & $20.20 \mathrm{c}$ & $9.60 \mathrm{~d}$ & $137.83 \mathrm{~d}$ & $137.303 \mathrm{~b}$ \\
\hline Diet 10 (G:V.E 1:35) & 4 & $19.43 \mathrm{~d}$ & $7.56 \mathrm{~d}$ & $149.33 \mathrm{c}$ & $152.33 \mathrm{a}$ \\
\hline Diet 11 (G:V. E 1:40) & 4 & $20.54 \mathrm{c}$ & $7.36 \mathrm{ed}$ & $161.0 \mathrm{a}$ & $152.33 \mathrm{a}$ \\
\hline Standard error & & \pm 0.22 & \pm 0.14 & \pm 2.59 & \pm 3.15 \\
\hline
\end{tabular}

Averages followed by different letters in each column are significantly different $(\mathrm{P}<0.05)$

\section{Proximate analysis of the whole body:}

The highest moisture content of fish whole body (Table 5) was recorded for fish groups fed the diets diet7 and diet 10 and the lowest moisture content was recorded in fish groups fed the diets diet 3 and diet 5 . The increasing levels of vitamin $\mathrm{E}$ in the experimental diets did not significantly affected moisture content of the fish whole bodies. Protein content of the whole fish ranged between 41.33 to $50.97 \%$ and the differences in protein content were significant. Incorporation of vitamin $\mathrm{E}$ in the experimental diets (diet2, diet3 and $\operatorname{diet} 4)$ significantly increased protein content of fish body as compared to fish fed control diet (diet 1) while the highest inorporation levels of vitamin $E$ in the experimental diets (D5, D6, D7 D10 and D11) significantly reduced protein content of fish whole body compared to fish in control group.

The highest fat content of the fish whole body was recorded in fish group fed on the diet D2 (in which fish meal was completely replaced by CSM without incorporation of vitamin $\mathrm{E}$ in the diet). The fat content of fish fed the diet D2 significantly higher that the fish fed the other groups but the differences between the other fish groups were not significant and the differences in ether extract were significant $(\mathrm{P}<0.001)$.

Compared to the two control diets D1 and D2 all vitamin levels in the experimental diets increased ash content of the fish whole body and the graded levels of vitamin $\mathrm{E}$ in the diets significantly altered the ash content of tilapia fish. 
Table 5: Least square means and standard error for the effect of replacing fish meal by cotton seed meal and different levels of V.E in Nile tilapia diets on proximate analysis of the whole fish.

\begin{tabular}{|l|c|l|c|c|c|}
\hline Diets & No.+ & Moisture & CP & EE & Ash \\
\hline Diet 1 (Control) & 8 & $72.38 \mathrm{bdc}$ & $45.77 \mathrm{~b}$ & $21.44 \mathrm{~b}$ & $10.79 \mathrm{~b}$ \\
\hline Diet 2 (CSM) & 8 & $73.50 \mathrm{ba}$ & $50.97 \mathrm{a}$ & $23.62 \mathrm{a}$ & $10.87 \mathrm{ba}$ \\
\hline Diet 3(G:V. E) (1:1) & 8 & $71.68 \mathrm{ed}$ & $50.72 \mathrm{a}$ & $21.76 \mathrm{~b}$ & $11.24 \mathrm{ba}$ \\
\hline Diet 4 (G:V. E) (1:5) & 8 & $72.46 \mathrm{bdc}$ & $50.23 \mathrm{a}$ & $22.75 \mathrm{ba}$ & $11.04 \mathrm{ba}$ \\
\hline Diet 5 (G:V. E) $(1: 10)$ & 8 & $71.83 \mathrm{edc}$ & $46.72 \mathrm{~b}$ & $21.74 \mathrm{~b}$ & $11.54 \mathrm{ba}$ \\
\hline Diet 6 (G:V. E) (1:15) & 8 & $72.40 \mathrm{bdc}$ & $41.99 \mathrm{~cd}$ & $21.95 \mathrm{~b}$ & $12.01 \mathrm{a}$ \\
\hline Diet 7 (G:V. E) (1:20) & 8 & $74.23 \mathrm{a}$ & $44.47 \mathrm{cb}$ & $21.28 \mathrm{~b}$ & $11.25 \mathrm{ba}$ \\
\hline Diet 8 (G:V. E) (1:25) & 8 & $73.45 \mathrm{ba}$ & $45.10 \mathrm{~b}$ & $22.63 \mathrm{ba}$ & $11.10 \mathrm{ba}$ \\
\hline Diet 9 (G:V. E) (1:30) & 8 & $73.12 \mathrm{bc}$ & $47.46 \mathrm{~b}$ & $21.47 \mathrm{~b}$ & $12.05 \mathrm{a}$ \\
\hline Diet 10 (G:V. E) (1:35) & 8 & $74.42 \mathrm{a}$ & $41.33 \mathrm{~d}$ & $21.38 \mathrm{~b}$ & $11.57 \mathrm{ba}$ \\
\hline Diet 11 (G:V. E) (1:40) & 8 & $73.50 \mathrm{ba}$ & $41.33 \mathrm{~d}$ & $22.26 \mathrm{ba}$ & $11.29 \mathrm{ba}$ \\
\hline Standard error & & \pm 0.44 & \pm 0.97 & \pm 0.531 & \pm 0.37 \\
\hline
\end{tabular}

Averages followed by different letters in each column are significantly different $(\mathrm{P}<0.05)$.

\section{REFERENCES}

Alford, B. B.; Liepa, G. U. and Vanbeber, A. D. (1996). Cottonseed protein: what does the future hold?. Plant Foods Human Nutrition, 49:1-11

Anderson, J. S. and Sunderland, R. (2002). Effect of extruder moisture and dryer processing temperature on vitamin $\mathrm{C}$ and $\mathrm{E}$ and astaxanthin stability. Aquaculture, 207: 137-149.

AOAC (Association of Official Analytical Chemists) (1990). Official Methods of Analysis. $15^{\text {th }}$ edn. AOAC, Arlington, VA, USA.

Barros M.M.; Lim C. and Klesius P.H. (2002). Effect of soybean meal replacement by cottonseed meal and iron supplementation on growth, immune response and resistance of channel catfish (Ictalurus punctatus) to Edwardsiella ictaluri challenge. Aquaculture, 207: 263-798.

Boyd, D. (1979). Water Quality in Warmwater Fish Ponds. Auburn University Agricultural Experiment Station, Auburn, AL.

Brown, B. A. (1988). Routine hematology procedures., In: Hematology: Principle and Procedures (ed, by B. A. Brown). pp. 7-122. Leo and Febiger, Philadelphia, PA. USA.

Cho, C. Y. and Kaushik, S. J. (1985). Effect of protein intake on metabolizable and net energy values of fish diets. In: Nutrition and Feeding in Fish (ed. 
by C.B. Cowey, A.M. Mackie \& J.G. Bell), pp. 95- 117. Academic Press, London, UK

Colin-Negrete J.; Kiesling H.E.; Ross T.T. and Smith J.F. (1996). Effect of whole cottonseed on serum constituents, fragility of erythrocyte cells, and reproduction of growing Holstein heifers. J. Diet. Sci., 79:2016-2023.

Dabrowski, K.; Rinchard, J.; Lee, K.-J.; Blom, J.H.; Ciereszko, A. and Ottobre, J. (2000). Effects of diets containing gossypol on reproductive capacity of rainbow trout (Oncorhynchus mykiss). Biol. Reprod., 62:227- 234.

Dorsa, W. J.; Robinette, H. R.; Robinson, E. H. and Poe, W.E. (1982). Effects of dietary cottonseed meal and gossypol on growth of young channel catfish. Trans. Am. Fish. Soc., 111: 651-655.

El-Saidy D. M. and Gaber M. M. A. (2002). Complete replacement of fish meal by soybean meal with the dietary L-lysine supplementation in Nile tilapia fingerlings. J. World Aquacult. Society, 33:297-306.

El-Saidy D. M. and Gaber M. M. (2003). Replacement of fish meal with a mixture of different plant protein sources in Juvenile Nile tilapia diets. Aquacult. Res. 34: 1119-1127.

El-Saidy, D. M. and Gaber, M. M. (2004). Use of cottonseed meal supplemented with iron for detoxification of gossypol as a total replacement of fish meal in Nile tilapia Oreochromis niloticus (L.) diets. Aquacult. Res., 35: 859-865.

El-Sayed, A. M. (1990). Long-term evaluation of cottonseed meal as a protein source for Nile tilapia Oreochromis niloticus (Linn.). Aquacult., 87:315320.

Frischknecher R.; Wahli T. and Meier W. (1994). Comparison of pathological changes due to deficiency of vitamin $\mathrm{C}$, vitamin $\mathrm{E}$ and combination of vitamin $\mathrm{C}$ and $\mathrm{E}$ in rainbow trout, (Oncorhynchus mykiss, Walbaum). J. Fish Diseases. 17:31-45.

Fu, Y.F.; Zhang S.L.; Lu Z.M. and Wang W. (1988). Effect of gossypol on the activity of kidney $\left(\mathrm{Na}^{+}+\mathrm{K}^{+}\right)$-ATPase and the function of erythrocyte membrane. Contraception 37:179-184.

Garcia-Abiado, M. A.; Mbahinzireki, G.; Rinchard, J.; Lee, K. J. and Dabrowski, K. (2004). Effect of diets containing gossypol on blood 
parameters and spleen structure in tilapia, Oreochromis sp., reared in a recirculating system. J. fish Diseases. 27: 359-368.

Herman, R. L. (1970). Effects of gossypol on rainbow trout (Salmo gairdneri). J. Fish Biol., 2:293-297.

Hibiya T. (1982). An Atlas of Fish Histology-Normal and Pathological Feattures. Kodanasha Ltd, Tpkyo.

Jackson, A. J.; Capper, B. S. and Matty, A. J. (1982). Evaluation of some plant proteins in complete diets for the tilapia S. mossambicus. Aquacult. 27: 97-109.

Jones, L.A. (1987). Recent advances in using cottonseed products. Proceedings of the Florida Nutrition Conference, 12-13 March 1987, Daytona Beach, FL, pp. 119-138.

Lee, K. J.; Rinchard, J.; Dabrowski, K.; Babiak, I.; Ottobre, J. S. and Christensen, J. E. (2006). Long-term effects of dietary cottonseed meal on growth and reproductive performance of rainbow trout: three-year study. Animal Feed Science and Technology, 126:93-106.

Martin S.D. (1990). Gossypol effects in animal feeding can be controlled. Feedstuffs, 62:14-17.

Middendorp, A. J. (1995a). Pond farming of Nile tilapia (Oreochromis niloticus L.) in northern Cameroon. Feeding combination of cottonseed cake and brewery waste in fingerling culture, hand-sexed male monosex culture, and mixed culture with police-fish, Clarias gariepinas (Burchel).Aquacult. Res. 26: 715-722.

Middendorp, A. J. (1995b). Pond farming of Nile tilapia,(Oreochromis niloticus) (L.) in northern Cameroon. Mixed culture of large tilapia $(>200 \mathrm{~g})$ with cattle manure and cottonseed cake as pond inputs, nad African catfish Clarias gariepinus (Burchell), as police-fish. Aquacult. Res.26: 723-730.

Middendorp, A. J. and Huisman, E. A. (1995). Pond farming of Nile tilapia, Oreochromis niloticus in northern Cameroon. Comparing two different strategies for feeding cottonseed cake in tilapia male monosex culture. Aquacult. Res. 26, 731-738.

Moccia R. D.; Hung S.S.; Slinger S. J. and Ferguson H.W. (1984). Effect of oxidized fish oil, vitamin $\mathrm{E}$ and ethoxyquin on the histopathology and 
hematology of rainbow trout, Salmo gairdnerii Richardson. J. Fish Disease 7: 269-282.

Nikokyris P.N.; Kandylis K. and Deligiannis K. (1999). Effect of varying levels of dietary free gossypol in whole cottonseed on physiological response of growing-fattening lambs. J. Sci. Food and Agricult.79: 1969-1981.

NRC (National Research Council) (NRC) (1993). nutrient requirement of fish. National Academy Press Washington D. C.

Randel, R.D.; Willard, S.T.; Wyse, S. J. and French, L. N. (1996). Effects of diets containing free gossypol on follicular development embryo recovery and corpus luteum function in Brangus heifers treated with bFSH. Theriogenology.45: 911-922.

Reitman, S. and Frankel, F. (1957). A colorimetric method for determination of oxaloacetic transaminase and serum glutamic puruvic transaminase. A. J. Clin. Path 28:56-60.

Rinchard, J.; Mbahinzirereki, G.; Dabrowski, K.; Lee, K-J.; Garcia-Abiado, M. A. and Ottober, J. (2000). Effects of partial or total substitution of fish protein with cottonseed meal in diets on reproductive parameters of tilapia Oreochromis sp. Aquacult. America, Feb 2-5, 2000 New Orleans. P-282.

Rinchard, J.; Mbahinzireki, G.; Dabrowski, K.; Lee, K.-J.; Garcia-Abiado, M. A. and Ottobre, J. (2002). Effects of dietary cottonseed meal protein level on growth, gonad development and plasma sex steroid hormones of tropical fish tilapia Oreochromis sp. Aquacult. Int. 10:11-28.

Robinson, E. R.; Rawles, S. D.; Oldenburg, P. W. and Stickney, R. R. (1984). Effects of feeding glandless or glanded cottonseed products and gossypol to Tilapia aurea. Aquacult. 28: 145-154.

Robinson, E.H. and Li, M. H. (1994). Use of plant proteins in catfish feeds: replacement of soybean meal with cottonseed meal and replacement of fish meal with soybean meal and cottonseed meal. J. World Aquac. Soc. 25: $271-276$.

SAS, (1996). SAS Procedure Guide "version 6.12 Ed". SAS Institute Inc., Cary, NC, USA.

Sealey, W.M.; Lim, C. and Klesius, P.H. (1997). Influence of the dietary level of iron from iron methionine and iron sulfate on immune response and 
resistance of channel catfish to Edwardsiella ictaluri. J. World Aquacult. Soc. 28: 142-149.

Wilson, R. P.; Robinson, E.H. and Poe, W.E. (1981). Apparent and true availability of amino acids from commomn feed ingredients for channel catfish. J. Nutr. 111: 923-929.

Yang, W. and Xiang, S. (1995). The separation of gossypol enantiomers by $\mu$ Bondapak $\mathrm{C}_{18}$ column; Chim. J. Chromatogr., 13: 264-266. 